\title{
The responsibility of the teacher to the student performer
}

\author{
Krasimira Georgieva Fileva-Ruseva \\ Faculty of Music Pedagogy, Academy of Music, Dance and Fine Arts - Plovdiv, Bulgaria, Europe \\ Email address: \\ krassyfilleva@abv.bg
}

To cite this article:

Krasimira Georgieva Fileva-Ruseva. The Responsibility of the Teacher to the Student Performer. International Journal of Literature and Arts. Special Issue: Musical Theory, Psychology and Pedagogy. Vol. 2, No. 5-1, 2014, pp. 20-24. doi: 10.11648/j.ijla.s.2014020501.14

\begin{abstract}
The responsibility of the musical instrument teachers to their students is manifold. It includes the initial assessment of the abilities of the child, the development of the professional qualities, skills and dexterity of the student, the building of a stock of knowledge (basic note cognition, the fundamentals of the musical theoretical knowledge, general musical and stylistic culture), the responsibility to build up a strong motivation for playing a musical instrument, to develop determination and precise control over one's own performance and to promote a level of self-confidence, adequate to the abilities of the student. Whereas you may come across some publications about the first enumerated responsibilities, the topic about the needed self-confidence of the performer is usually neglected by the authors of methodical studies. The self-confidence of the musician - interpreter should not be either excessive or unduly low, because they both could be an obstacle as to the successful performance before listeners, so to the professional and even the life fulfilment of the instrumentalist.
\end{abstract}

Keywords: Music, Performer, Musical Instrument Teacher

\section{Introduction}

My position as a high school lecturer in arts enables me to work for the development of the necessary professional qualities of the music performers, as well as to observe the accomplishments of a great number of young musicians instrumentalists, who are just beginning to "fight" for the attention of the audience. My own experience as a performer is as useful as that, because I have passed through all the stages of education and have witnessed the pedagogical successes and mistakes while I was being educated, alongside other students of my age, who today are my fellow music performers. The observing of the development of the musician-interpreter from their first steps to their mature age, as well as the results of the work of many teachers in musical instrument prompted me to write this article.

\section{The Assessment of Pupil's Qualities}

From the very first contact with the little pupils, the teacher carries a responsibility to them and this is expressed in the evaluation of their qualities. This evaluation concerns not only the musical qualities of the child - it is considerably more general and represents the clear opinion as to how much this student is capable of developing as a professional musician, or he/she should rather be tutored to become an educated connoisseur of the tonal art. The inaccurate evaluation of the student's qualities could lead to the child's futile attempts to cope with requirements, too hard for him/her because the particular student does not have the necessary capabilities, or to the refusal to take professional care of a talent which is yet to start developing. The assessment of the teacher includes:

\subsection{The musical Capabilities}

Whereas some of the remaining qualities could undergo a considerable positive change under proper education, the existence of musical abilities is necessary beyond doubt at the very start of the musical classes of the future professional. The musical qualities are the mode sense, methro-rhythmic sense, musical auditory notions and their derivative sense of polyphony. While the last two enumerated abilities develop more during the education, the availability of the first two, although they will be further developed, too, is a determinative factor for the overall success of the musical classes.

\subsection{The Artistic Quality}

Without the capability to re-create a given musical image, without stage presence, i.e. without the ability to attract and 
hold the attention of the audience, the musicians will not be able to cope with the responsibility to present to the listeners the work that has been assigned to them; they will not manage to convey the feelings which the composer has put in the work. Nor will they be able to cope with the great rivalry of capable and artistic performers which is a global issue. And naturally, these capabilities develop in the course of education but their definite existence is necessary as early as the very start. Here, very valuable is the ability of the teacher to foresee and discern the future development of the possible artistic qualities in the students.

\subsection{The Child's Motivation to Study Music}

The willingness to be occupied with musical art is very important for the student. If the child at an early age has shown interest in another field of human activity, regardless of the degree of musical abilities, he/she should not be forced to study music professionally. A successful approach is to still have the initial classes, but less intensively. The capable student could show wish to study a musical instrument subsequently and, at that, the personal qualities will create the necessary conditions for the child's future accelerated development. While working with such a student, it is appropriate to emphasize a bit more on the influencing "might" of the tonal art; the freedom to depict and express everything through music even things that cannot be expressed though words; the effect that a meaningful performance has on the people experiencing it; and the power of music to captivate the senses of the audience and even to heal. Realizing the huge opportunities of musical art could be the necessary motive for the student to achieve the so important irreversible interest in this human activity and it could help to "see" himself/herself as a professional performer. Forcing the child to study something he/she is not interested in, on the one hand could prevent the student from excelling in a different field for which he/she is even more capable and more motivated. And so the student, studying a musical instrument intensively, could waste precious time for the development of other needed qualities. On the other hand, by disrespecting the inclinations of the children, you may push them to develop in a field, undesired by them. Even if such a student becomes a professional musician, he/she frequently would experience crisis in the motivation for work and often would come to the impasse "burnout", this student would seek an opportunity to "evade" the frequent performance obligations. A more favourable option of this is to direct his/her efforts to "rescue" marginal fields related to music like musical criticism and journalism, musical psychology, musical therapy and sound engineering.

\subsection{The Dexterity}

When the child is too young, this quality is hard to be defined but the presence of dexterity is extremely important for the successful career of the performer.

\subsection{Specific Properties of the Locomotor System}

Its assessment is not of crucial importance to the decision of the teacher because it naturally will undergo development. With the initial estimation, the fact that the motor apparatus should be able to endure a great number of specific burdens has to be taken into account.

\section{The Responsibility of the Teacher during the Studies}

Alongside with the development of musical thinking, learning the musical expressive means, achieving the needed technical skills, developing a broad stylistic and general musical culture, as well as building on the musical capabilities and artistic qualities, the presence of which should be noticeable at the very start of the musical studies, during the work with the given student, the responsibilities of the teacher include as well:

\subsection{Building up the Strong Motivation of the Student}

The teacher should raise the curtain on the huge representational and expressive opportunities of the tonal art before the child. This, however, is just one of the approaches of pedagogical influence. The creative teacher-student relationship is also very important because the student, especially at an early age, is prone to transfer his/her attitude towards the teacher on the very subject itself, in this case on the musical instrument, being studied. The educator should treat the students in such a way as to be their personal example, a favourite teacher, not the type which the young artists would strive to forget as soon as their education with that person comes to an end. The teacher should remember that, without exaggeration, thousands of hours of exercises lie ahead of the child, for which he/she should spare the needed time every day and should do it with readiness. Another thing the teacher must not forget is that, in the course of studying, there will also be some failures and the teacher should be especially tactful in these cases. This reminder is important because, for that moment, the teacher is the main "authority" who can express his/her professional opinion and whose estimation is carefully listened to, and, being not yet firmly rooted, the young student is acutely sensitive to the remarks on his/her own accomplishments and to "attacks" and repression on the artistic ego in the course of the studies.

\subsection{Cultivating the Volitional Qualities, Self-Discipline and Self-Control}

The thousands of hours of work, I mentioned above, will not be carried out if the student, with the help of the teacher, does not train the needed qualities, like self-discipline. Stoicism is also necessary; it is needed to defend the choice of a musical profession against the demonstrated lack of understanding coming from other children; strict organization, because, besides the school subjects, studied 
by everyone, the musician has to find extra time on a daily basis - to study for some musical disciplines that are compulsory for him/her, to practice playing a great number of tonal pieces, to master instrumental skills. Some of the musical plays that are in the curriculum are not so enjoyable and liked by the students as others. In the course of studying, a large amount of instructive literature has to be learned; a considerable part of it does not possess the aesthetic qualities and the emotional impact of a work of art. Notwithstanding that, etudes and technical exercises should be played out thoroughly, because the subsequent progress in learning the instrumental skills depends considerably on this. When the students practice on their own, the habit of focusing on the material, being studied, is of crucial importance, no matter if the subject is instructive or artistic, liked or disliked, read for the first time, i.e. unknown or has been practised repeatedly or even "had grown boring", if this activities are to have effect. Having control over his/her own performance is also of great importance for the effectiveness of the self-reliant studying because the inability to listen critically to one's own playing and to find the different kinds of faults leads to repeating mistakes of the same kind and to them becoming a common practice.

\subsection{Building up the Performer's Conception for a Specific Work}

The student should be trained to be precise in the musical text, this including not only the correct reading of the notes, but also accuracy to the author's prescriptions for applying the performer's means of expression - dynamics, articulation, agogics, tempo as well as performance means, specific for the particular musical instrument. The bringing up of correct attitude towards the music performed is another responsibility of the teacher. The truthful interpretation of a work presupposes also the presence of rich stylistic culture of the student, accumulation and assimilation of information about the studied works and their authors, about the historical period during which the studied opus has been created, about the performing style of the composer in case he was a performer as well and if there exists information about that. The teacher needs to direct the student to authentic sources of the necessary information but at the same time teach the student to look for such information conscientiously about each work that he/she would prepare.

\subsection{Teaching Stage Behaviour}

Indeed, such behaviour has as its "prehistory" the rehearsing of the specific works performed before the audience, as well as the overall preparation of the instrumentalist who is also an interpreter of the author's idea and a mediator between the composer and the listeners. In the works, that will be presented, the instrumental difficulties must be mastered and the student has to be sure about the truthfulness of his/her interpreter's vision about the works, to have learned them by heart. These three conditions are extremely important, because the fear of forgetting the notation, the fear of technical failures, of insufficient preparation, as well as the fear of unconvincing interpretation are the main stressors in the stage stressful situation, i.e. the basic reasons for the performer to be uncertain before the audience. In the specific stage situation (for students, the basic types of stage situation are a concert or an exam - class meetings and productions carry the characteristics of a concert situation, competitions with their conditions are similar to the exams) the conduct comprises a truthful interpretation of the emotional world of the given work, calmness, limiting the unfavourable manifestations of stage stress, emotional effect over the listeners, holding their attention and interest. The stage behaviour of the student is to a considerable degree the responsibility of the teacher, but this responsibility is sometimes neglected. During their stage appearances, the orchestra instrument musicians usually have the support of the accompanist (really, it is not very significant, but it is there, nevertheless); during a solo performance, however, the piano player is alone before the audience which brings additional stress to him/her. In order the stage anxiety to be overcome, it is of great importance that the teacher does not allow a student, who has not yet learned the repertoire reliably, to perform before audience, because there is a great possibility that the still not proficient artist will not be able to manage and each failure will have a very unfavourable effect on the future performances of that student. Before a serious appearance, a preliminary "audition" of the repertoire, being rehearsed for the official performance, should be staged or even several such auditions before a limited circle of listeners should be conducted. In case this moment of the preparation is overlooked, it is very likely that the not yet proficient instrumentalist will not be able to endure the increased requirements to him/her and to perform convincingly. In the last days before the performance, for which the student and the teacher have worked hard, it is necessary resting conditions to be provided for the student - he/she should not be overburdened with prolonged exercises, which are not only useless, but could also be harmful - a considerable part of the adaptation energy may be exhausted in this way resulting in the deficiency of that energy during the very performance. I myself had two cases of failure in my practice as a performer (they occurred in two successive days during my education) and were the result of a serious overwork, not in conformity with my age at the time. After a successful performance the young artists should be stimulated and in case of failure they should be treated most tactfully.

\subsection{Self-Confidence}

An especially important responsibility when building up the image of the future instrumentalist concerns the creation of conditions of self-confidence, adequate to the capabilities and the real accomplishments of the performer. The necessity of inciting strong student's motivation for attending piano lessons and cultivating their will-power is 
mentioned in several publications. Unlike these topics, the question of the much-needed performers`confidence and the trust in their own abilities usually stay aside from the attention of the authors of papers with a methodical orientation. This kind of self-confidence should be cultivated carefully and to a certain degree, it should neither be excessive, nor unjustifiably low - both factors could hinder not only the successful representations before the audience, but also the overall professional realization and the success in the personal life of the performer. In the introduction I mentioned that in the course of my studies and later on as a piano pedagogue and a professional performer I have had the opportunity to observe carefully the professional development of many musicians. I remember clearly a lady, a performer of a stringed instrument, whose teacher and parents "carefully" and steadily built her impression that she was a genius. Indeed, she was a skilful instrumentalist but not a genius. The audience did not accept her the way she had expected. After many concerts, successful in their essence, but not in the least constituting the world-wide career for which she had prepared herself so diligently and dedicatedly and for which she had regarded herself as predestined, the performer gradually lost her desire to play, lost her everyday contacts with colleagues, as well as her friends, her motivation and belief in herself. Having sacrificed all her life in the name of this career, having remained without life experience, without forces of resistance against the vicissitudes of fortune and having missed all chances of an adequate to her abilities professional realization and even of starting her own family which could have given a meaning to her hours free from work, she was overcome by a heavy depression and at the moment is being treated with medicines and is unemployed. Another example is an instrumentalist also "exalted" by parents and teachers with a prestigious work and social status, who has formed a steady family of her own and has achieved a successful professional realization within Bulgaria but... only that. For many performers, that could be enough but not for "the child kissed by God", as a close family friend would put it. And now being in her years before pension, incapable of accepting and appreciating anything which is not her own performance achievement, having lived from an early age with the self-confidence that she was not even "the first one" but "the one and only", she had become acerbated against everyone who had been successful, even if less than her, and in the course of time she got more and more isolated, her acquaintances being left with bad memories of her. And yet another characteristic case of "overestimated" self-confidence of an instrumentalist praised by teachers and protected and zealously defended by parents, having received a good professional realization for his capabilities. After graduating from university and embarking on a respectful profession, he carefully started building up "a wall" of subordinates and subservient toadies who praise him assiduously and support his high self-confidence. So, gradually he started living "in his own world". At present, not all of his stage performances are at a very high level, partly because he is not in such a good form anymore, as he used to be in his youth, partly because "the bullet-proof" wall of people, constantly admiring him, does not allow him to objectively assess the material which he chooses for his appearances before the audience, nor the very quality of the performance itself and naturally he is not able to find the reasons for his "imperfections" and also to avoid future failures. And another case, contrary to the mentioned above, of a very talented but emotionally hurt pianist, trained in a class of laureates of international competitions, having concerts in the country and abroad, constantly compared with them by his teacher (a very successful teacher but clearly not so successful in teaching all of his students). These tactless comparisons and naggings that the performances of this student were not so exceptional and perfect, as those of his classmates, that he allowed himself some faults when performing before an audience ruined his self-confidence. Craving for recognition, for a creative attitude to his talent but with more delicate psyche, for support but not for the impatience, demonstrated every single day, he was unable to realize the huge potential he possesses. And another case of a lady instrumentalist - she was constantly required to deliver performance achievements without hearing a simple word of praise, though she played really well at concerts. She has found the stoicism to become a successful musical pedagogue but her performance appearances before the audience are very rare, though they are influencing and of high quality.

\section{Results}

1. The teacher of musical instrument is a very important figure not only in establishing the instrumental skills, general musical culture and in the development of the musical capabilities of the student, but also in building his self-esteem.

2. Due to the importance of the teacher as the authoritative person in the relationship teacher student, the latter usually has an uncritical attitude to the assessment his/her abilities and development, which the pedagogue prompts during the classes.

3. Infatuated by the striving to achieve the highest pedagogical outcomes, the teacher often ignores the self-assessment of the pupil with the result that the pedagogue not always succeeds in building an adequate to the learner's abilities self-confidence.

4. If the pedagogue neglects this important element of the relationship teacher - student, often the self-assessment of the learner is deformed.

5. As a result the confidence of both the professionally unstable learners and the mature interpreters does not always correspond to their abilities.

6. The inadequate self-esteem has unfavorable effects on the behavior, in some cases - on the professional realization, and may even affect the realization in life and the health of the performer. 


\section{Discussion}

The displayed results are valuable by the following:

1. Observations on the impact of the behavior of the pedagogue on the professional and life path of many students and mature music interpreters are made and summarized.

2. The professional and the life realization of many instrumentalists has been followed in development from the early relationships with their teachers, till the adulthood.

3. Each of the examples, adduced in connection with the confidence of the professional music performer, is the most obvious example of each of the different directions of change in the behavior of instrumentalists due to their inadequately built self-esteem.

4. Through the examples is proven that the pedagogue bears a far vaster responsibility for the development of the student than usually is realized.

5. The issue about the responsibility for the self-confidence of the performer-instrumentalist, despite its importance, is not the subject of research in the literature on the methodic of teaching a musical instrument, although exactly that kind of literature is used by the teachers of musical instrument.

\section{Conclusion}

Drawing the attention of the educators, preparing professional music performers, to the serious problem of their responsibility for the self-assessment and the self-confidence of their students can prevent the professional and life failures of many musicians.

The duty of the teacher to the student also includes the personal example. The teacher in a musical instrument has to be hard-working, equitable, affable, patient, artistic and original. He/she needs to explain the material both captivatingly and convincingly but should also do it in such a way that all the students would understand, the teacher should possess rich musical and general culture. The pedagogue also has to be a skilful interpreter, tactful and benevolent towards all the students, and the teacher's criticism, whenever needed, should be invariably constructive.

\section{References}

[1] Alexeev, A. D. History of Piano Art, p. I and II. M. 1988 (Алексеев, А. Д. История фортепианного искусства, ч. I и II. M. 1988)

[2] Alexeev, Alexander. Interpretation of Musical Works. Based on the Analysis of the Art of the Greatest Pianists of the 20th Century. Moscow, 1984 (Алексеев, Александр. Интерпретация музыкальных произведений. На основе анализа искусства выдающихся пианистов XX века. М, 1984)

[3] Berkman, Tamara L. and K.S. Grishtenko. Musical Education of the Teacher. Moscow, 1956 (Беркман, Тамара Л. и К. С.
Грищенко. Музыкальное образование учителя. Москва, 1956)

[4] Cortot, A. Studies in Musical Interpretation. Sofia, 1959 (Корто, А. Курс по интерпретация. С, 1959)

[5] Gieseking, W. Thus I Became a Pianist. N: Performance Art in Foreign Countries, issue 1 (Гизекинг, В. Так я стал пианистом. В: Исполнительское искусство зарубежных стран, вып. 1)

[6] Golubovskaya, N. O. Of Musical Performance. L. 1985 (Голубовская, Н. О. О музыкальном исполнительстве. Л. 1985)

[7] Hoffman, Y. - Piano Playing. With Piano Questions Answered. Moscow, 1961 (Гофман, Й. - Фортепианная игра. Ответы на вопросы о фортепианной игре. М. 1961)

[8] Kogan, G. At the Gates of Mastery. The Work of the Pianist. Moscow, 1961 (Коган, Г. У врат мастерства. Работа пианиста. Москва, 1961)

[9] Levin, Yosif. Basic Principles of Playing the Piano. Moscow, 1978 (Левин, Йосиф. Основные принципы игры на фортепиано. Москва, 1978)

[10] Libermann, E. Y. - Work on the Piano Technique. Moscow, 1985 (Либерман, Е. Я. - Работа над фортепианной техникой. М. 1985)

[11] Martinsen, K. A. Individual Piano Technique Based on the Will to Make Sounds. Moscow, 1966 (Мартинсен, K. А. Индивидуальная фортепианная техника на основе звукотворческой воли. Москва, 1966)

[12] Michel, Paul. Musical Abilities and Performance Skills. Contribution to Musical Psychology. Sofia, 1980 (Михел, Паул. Музикални способности и изпълнителски сръчности. Принос към музикалната психология. С. 1980)

[13] Motov, V. and L. Gavrilov. Working on Piano Pieces. Moscow, 1961 (Мотов, В. и Л. Гаврилов. Работа над фортепианным произведением. Москва, 1961)

[14] Neuhaus, H. Of the Art of Piano Playing. Moscow, 1967 (Нейгауз, Г. Об искусстве фортепианной игры. Москва, 1967)

[15] Rabinovich, D. A. Performer and Style. Selected Articles. Issue 1. Moscow, 1979 (Рабинович, Д. А. Исполнитель и стиль. Избранны е статьи. Вып. 1. М, 1979)

[16] Savshinsky, S. Work of the Pianist on Musical Pieces. Moscow, 1964 (Савшинский, С. Работа пианиста над музыкальным произведением. Москва, 1964)

[17] Schmidt-Shklovskaya, A. A. Of Training Pianist Habits. Leningrad, 1985 (Шмидт-Шкловская, А. А. О воспитании пианистических навыков. Ленинград, 1985)

[18] Shulpyakov, O. F. Technical Development of the Musician Performer. Methodology Problems. Leningrad, 1973 (Шульпяков, О. Ф. Техническое развитие музыканта-исполнителя. Проблемы методологии. Ленинград, 1973)

[19] Stoyanov, A. Methodology of Teaching Piano. Sofia, 1957 (Стоянов, А. Методика на обучението по пиано. С. 1957)

[20] The Mastery of the Musician Performer. Issue 1, 2, Moscow. 1976 (Мастерство музыканта-исполнителя. Вып. 1, 2, М. 1976) 